\title{
INNOVATION OUTCOMES OF SOUTH AFRICAN NeW TECHNOLOGY-BASEd FIRMS: A CONTRIBUTION TO THE Debate on the Performance of Science Park Firms
}

\author{
Kai-Ying A Chan \\ Graduate School of Technology Management, University of Pretoria
}

Leon AG Oerlemans

Department of Organisation Studies \& Center for Innovation Research, Tilburg University and Graduate School of Technology Management, University of Pretoria

Marthinus W Pretorius

Graduate School of Technology Management, University of Pretoria

Accepted: April 2011

\begin{abstract}
Science parks are often established to drive regional economic growth, especially in countries with emerging economies. However, mixed findings on the innovation outcomes of science park firms are reported in the literature. This study systematically identifies innovation outputs used in the science park literature and argues: (a) that firms generate different outcomes at various stages of the innovation process; and (b) that their use is a possible explanation for the mixed findings reported in the field. This paper combines a knowledge production function approach, modeling knowledge transfers and spillover flowing to new technology-based firms (NTBFs) in the emerging South African economy with innovation outcomes, which are measured by using a multi-dimensional construct. The estimations produce non-consistent and non-systematic results across different dimensions of innovation outcomes, implying that results are outcome indicator specific and that it makes sense to distinguish multiple indicators of innovation outcomes referring to different phases in a firm's innovation process.
\end{abstract}

Key words: innovative outcomes, science parks, knowledge transfer, spillovers, new technology-based firms

JEL: D83, L14, O31

1

\section{Introduction}

By now, science parks are an established phenomenon. The concept can be traced back to the $1950 \mathrm{~s}$, when the Silicon Valley region, with the support of Stanford University, was transformed from an agricultural valley into the birthplace of the semiconductor and ICT industry. Following the USA experience in the 1960s, the development of the Cambridge Science Park (UK) and Sophia Antipolis (France) has set a good example for many European countries. The majority of the science parks that currently exist worldwide were created during the $1990 \mathrm{~s}$, while about
18 per cent of them were launched within the first two years of the new century. Today there are over 400 science parks in the world, concentrated primarily in countries with developed economies. Over 140 of them were established in North America.

The reason for this rapid growth of science parks around the world is the belief, held mostly by policy-makers in industrialized economies, that the establishment of these parks would promote economic growth and competitiveness among cities and regions by creating new business, adding value to companies, and creating new knowledge-based jobs (The International Association of Science Parks). The foundation of a science park is 
often used as a policy intervention to stimulate high technology start-ups (McAdam \& McAdam, 2008). This is where government provides infrastructure, industry provides business skills and funding, and universities provide research knowledge and new technological development; it is also known as the Triple Helix of university-industry-government relations for innovation (Etzkowitz \& Leydesdorff, 2000). An important function of any science park is to contribute to the establishment of a knowledge-based economy by fostering market-oriented technological development. This type of economy depends on three interrelated processes: local knowledge creation, transfer of knowledge from external sources and transformation of that knowledge into productive activities and valued outcomes (Chen \& Choi, 2004). Consequently, networking among firms and between firms and universities to transfer knowledge and foster collaboration and innovation are processes vital to science parks.

Despite the benefits that science parks might bring, researchers have been studying the science park phenomenon to analyze the extent to which science parks are just 'high tech fantasies' (Massey et al., 1992; Bakouros, 2002) or not (Yang et al., 2009). To ascertain the 'added-value' of a science park location, researchers believed comparative studies should be conducted (Westhead, 1997; Lindelöf \& Löfstsen, 2004). These studies compared the behavior and performance of firms located on a science park with firms that were not in order to explore the potential differences between them. Interestingly, in this literature researchers reported mixed empirical findings on the performance of science park firms. Some researchers found empirical evidence of the 'added-value' of science park location (e.g. Felsenstein, 1994; Lindelöf \& Löfstsen, 2004), whereas others clearly questioned the assumed benefits of the science park model (e.g. Westhead, 1997; Malairaja and Zawdie, 2008). The latter group of scholars found that there are no differences between on-park and off-park firms relating to their performance. Further details of these comparative studies will be elucidated in a later section. From observations on these studies, we can conclude that there are at best 'mixed' findings on the performances of science park firms. The mixed evidence in the empirical literature prompted us to ask the following question: Does the use of different innovation outcomes indicators explain the mixed findings reported in the literature? The observations in the later section pointed to the various dimensions of innovation outcomes used in the science park literature and suggested that the outcomes of innovation processes of science park firms can be observed at different stages of this process. This may be one of the main causes of the mixed findings.

This study contributes to the science park literature in three ways. First, it provides a review of the comparative studies on the performance of science park firms, indicating mixed empirical findings. This paper suggests that these mixed findings are due to the use of a portfolio of outcome measures, which can actually be related to the various stages of the innovation process through which firms proceed. Further, this paper investigates the extent to which knowledge resources transferred both intentionally and unintentionally play a role in the theoretical model developed. In other words, the link between knowledge transfer and firm innovativeness is explored with the result that two largely detached literatures, one on inter-organizational knowledge transfers and the other on knowledge spillovers, are combined in one study. Secondly, most science park studies use the number of 'patents' and 'new products/ services' (e.g. Westhead, 1997; Siegel et al., 2003; Akçomak \& Taymaz, 2004) as main indicators of firm innovative performance. These indicators give only a partial view of the multiple dimensions firm's innovation outcomes. In this study, innovation outcomes are conceptualized as a multi-dimensional construct and are thus measured with multiple indicators to come to a more encompassing view of the innovation performance of science park firms. Thirdly, most science park studies are conducted in developed economies, whereas the context for this study is an emerging economy, South Africa. Such empirical studies are relatively scarce, but highly relevant. In developed economies, science parks are often more easily and better 
connected to the rest of the system of innovation. This is not always true of emerging economies (Lorentzen, 2009), which often lack a well-developed, connected system of innovation. Consequently, firms located in science parks in emerging economies have to focus more strongly on the interaction with partners located in the same science park. Interaction with spatially proximate partners brings certain benefits, but also some potential disadvantages (Knoben \& Oerlemans, 2006), such as lock-in effects. This paper therefore adds to our knowledge of the functioning and outcomes of an interesting aspect of the innovation system in non-Western economy.

This empirical article is organized as follows. In the next section, the results of a literature review on the performance of science park firms will be presented. In section 3, the results of this review are included in the theoretical framework of this study and relevant hypotheses will be developed. Section 4 describes the research methodology applied in exploring our theoretical framework. Section 5 discusses the results of the analyses of data on South African new technologybased firms (NTBFs), focusing on firms' knowledge transfer behaviours and innovation outcomes. Section 6 provides concluding remarks and recommendations for policy makers and further studies.

\section{2}

\section{Science parks and mixed findings: a literature review}

What is known about the performance of science park firms as discussed in the recent literature? To answer this question, a literature search was conducted using Google Scholar, Science Direct, Swetwise and Proquest as search engines. Key words used were 'on-park firms', 'off-park firms', 'science park performance', 'science park evaluation', 'benefits of science parks' and 'added-values of science parks'. The main purpose of this literature review was to gain an overview of the empirical results and measures applied in past studies regarding science park firms. The details of the review are summarized in this study. ${ }^{1}$ Besides the names of the author(s), the following criteria were included:

- Country and period: Where and when was the research conducted? In particular we wanted to know the country in which a study was conducted, as collaborating cultures differ from country to country;

- Research focus: Which research questions do studies set out to answer? From this column the researchers' various foci can be deduced, as well as the existing lacunae;

- Research methodology: Which research methodologies do studies apply to answer their research questions empirically? In these two columns we can explore the 'commonly used' research methodologies. This gives an indication of the maturity of the field. Moreover, we could learn from these approaches in our own empirical study.

- Indicators of innovation outcomes: Which indicators of innovation outcomes of firms were used in the studies included in this review?

- Key results: Regarding the aspects studied: Do on- and off-park firms differ from one another? From this column, we can see which findings on science park performance are reported in the literature.

An initial observation after analyzing the literature is that Westhead, Lindelöf and Löfsten are very active researchers in this field of study. Moreover, most of the studies were conducted in the period between 2002 and 2004, using longitudinal data sets (ranging from three to ten years) which are necessary when examining indicators of firm performance such as 'employment growth' or the 'survival' of firms over time. The establishment of science parks increased from 1973 (IASP website) until 1987, after which there was a decline, followed by another increase from 1997 onwards. This growth-declinegrowth phenomenon in science park creation may be one of the reasons why more researchers, using comparative approaches, investigate the extent to which science parks bring benefits.

It was found that the majority of studies were conducted in Western countries (the UK, Sweden and Italy), while only a few took place within emerging economies (Israel, Malaysia 
and Taiwan). There is a clear absence of comparative studies in emerging economies. The collaborative culture differs from country to country. Western cultures (Western Europe, North America and Australia) are characterized as individualistic, whereas some nonWestern culture (Asian, South American and African) often are characterized as collectivist (Green et al., 2005). Differences between cultures may influence how firms (residing in a specific country) interact with one another.

Studies tend to focus on three areas: (1) Employment growth (Westhead \& Cowling, 1995; Colombo \& Delmastro, 2002; Ferguson \& Olofsson, 2004; Akçomak \& Taymaz, 2004); (2) Industry-academic links (Felsenstein, 1994; Löfsten \& Lindelöf, 2002; Lindelöf \& Löfsten, 2004; Akçomak \& Taymaz, 2004; Dettwiler et al., 2006); and (3) Innovativeness, as indicated by $R \& D$ inputs, outputs and productivity (Westhead 1997; Colombo \& Delmastro, 2002; Siegel et al., 2003; Akçomak \& Taymaz, 2004; Yang et al., 2009).

An examination of the measurements for innovation outcomes used in these studies gives a mixed picture: researchers apply patent counts (used eight times), followed by the number of new products/services (five times) and copyrights (three times). This finding indicates that researchers use a variety of innovation outcome measures.

As far as knowledge transfers are concerned the focus is mainly on the knowledge links with local universities. Other linkages, such as with business partners (e.g. buyers or suppliers) or with other science park firms, are often not taken into account. Moreover, researchers seem to focus on intended knowledge transfers, paying little attention to unintended knowledge transfer (knowledge spillovers).

From the methodological perspective, it can be noted that most studies used a 'matched sampling' approach to selecting 'comparable' off-park firm, in line with the properties of on-park firms. The two sample sizes are more or less equal, ranging from 40 to 139 for each paired sample. This finding shows a commonly-accepted way of sampling. All the studies used questionnaires and surveys to collect firm-level data. One exception was
Yang's study, in which panel data from a financial databank was used. This shows a trend in 'firm-level' analysis in exploring performance by science parks. Most studies used 'independent sample t-test' for continuous and discrete variables and the 'Chisquared test' for dummy variables. These two statistical analysis tests are commonly used when comparing variables from two independent samples and exploring any significant differences between the groups of firms to show the 'added-value' of science parks. Moreover, from this literature review it can be concluded that there is a lack of use of multivariate analysis to explore more finegrained and complex relationships between firm characteristics and performance (e.g. using multivariate regression analysis).

A comparison of the research findings in the studies included in our review reveals that there are mixed findings when it comes to the added value of science park location to firms:

- Employment growth: Some studies find no significant difference between on- and offpark firms (Westhead \& Cowling, 1995; Akçomak \& Taymaz, 2004; Ferguson \& Olofsson, 2004), whereas others report that on-park firms experience higher employment growth (Löfsten \& Lindelöf, 2002; Colombo \& Delmastro, 2002);

- Interactions with universities: Some studies report no significant difference between on- and off-park firms (Malairaja \& Zawdie, 2008), while others find that onpark firms experience higher levels of interaction with (local) universities (Felsenstein, 1994; Lindelöf \& Löfsten, 2004);

- R\&D outputs and productivity: Some studies find no significant difference between on- and off-park firms (Westhead, 1997; Colombo \& Delmastro, 2002; Lindelöf \& Löfsten, 2003, 2004), whereas others report that on-park firms have higher R\&D outputs and productivity (Siegel et al., 2003; Yang et al., 2009).

Studies report similar findings on specific indicators, but these do not support the 'promises' that science parks often make: 
- There are no differences between on- and off-park firms regarding sales/profitability (Löfsten \& Lindelöf, 2002; Ferguson \& Olofsson, 2004).

- There are no differences between on- and off-park firms regarding R\&D inputs (Westhead, 1997; Colombo \& Delmastro, 2002).

From the mixed findings observed, it can clearly be seen that not all science parks deliver on their promises to bring 'addedvalue' to their firms and connected regions. In this section it is shown that there is a variety of possible different innovation outputs used, which can be connected to the various stages of the innovation process. In other words, some of the firms are in the early stages of their innovations, when they are seen as the inventor firms, and some of them are close to the full commercialization of their technological innovations. Finding different innovative outcomes could therefore result from the mixed types of innovations on which science park firms are working. In order to investigate this possible explanation further, this paper takes on a firm-level knowledge production function (Acs, Audretsch \& Feldman, 1994) as a starting point and asks the following research question: Does the use of different innovation outcomes indicators explain the mixed findings reported in the literature?

\section{Theoretical framework}

\subsection{Innovation process model and innovation outcomes}

In this study, the definition of innovation outcomes is based on the one proposed by Ernst (2001): an achievement in the trajectory from the conception of an idea up to the introduction of an invention into the market. Many studies use one dimensional conceptualizations only and thus single measurements of innovative performance like 'patents' (e.g. Bottazzi \& Peri, 2003) or the number of new products introduced (e.g. Stock et al., 2002). With Ernst's definition in mind, one could look at innovation from the point of view of process, that is, looking at the whole innovation process cycle. Within this innovation process model, various phases could be identified: basic research, invention, product development, and production, marketing and sales (Khilji, Mrockowski \& Bernstein, 2006). Certain types of innovation outcomes are associated with each phase. For example, patent outputs are associated with the initial stages, such as basic research and invention, whereas sales of innovative products are usually an indication of innovation outputs during the commercialization stage of production, marketing and sales. Consequently, innovation outcomes are a multi-dimensional construct that has to be measured with multiple indicators (see Figure 1).

Figure 1

The innovation process and innovation outcomes ${ }^{2}$

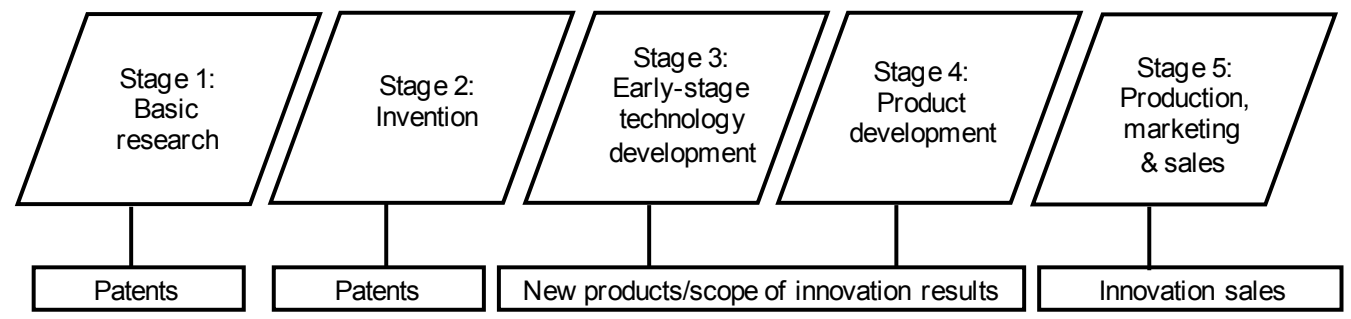

In each of the activity phases depicted in Figure 1, internal and external resources and capabilities are used to arrive at the outcomes mentioned. In the literature, this approach is referred to as the so-called modified knowledge production-function approach (Feldman, 1994), in which it is maintained that the acquisition of and the access to internal and 
external resources have to be combined with an effective internal utilization of these resources. Consequently, the absorptive capacity and resources have to be combined in one model (see below).

\subsection{Knowledge resources}

Knowledge is identified as a key resource for a technology-based firm's 'competitive advantage', because it is difficult to replicate and is critical to the process of innovation (Murmann, 2003; Thornhill, 2006; Ichijo \& Nonaka, 2007). In studies on innovation production functions, knowledge is often referred to as an important input (Hall \& Mairesse, 2006; Roper et al., 2008). Knowledge can be generated internally within a firm or obtained externally from other actors. For knowledge to be generated internally, a firm must have certain internal resources or capabilities for example, scientists or engineers doing in-house R\&D. Absorptive capacity as an important basis of a firm's innovative capability is a crucial internal resource (Tsai, 2001; Gao et al., 2008). In this age of increasing globalization and complex technological innovation, the use of internally-generated knowledge resources is no longer sufficient for technological innovation. Firms often acquire and use knowledge from external actors to complement their internal knowledge bases for innovative products or services development. Researchers have distinguished two categories of knowledge transfer: intended and knowledge transfers and spillovers (Fallah \& Ibrahim, 2004; Oerlemans \& Meeus, 2005). An intended knowledge transfer is a conscious and deliberate transfer of knowledge between two or more organizations often in the context of a formal collaboration agreement. On the other hand, knowledge spillovers refer to knowledge flows resulting from deliberate search activities by innovating firms, leading to an inflow of knowledge and information but without the formal consent of the owners of this knowledge and information.

\subsection{Absorptive capacity as internal knowledge activity}

Absorptive capacity was introduced by Cohen and Levinthal in 1990, who defined it as firms' fundamental learning processes, that is, their ability to identify, assimilate and exploit knowledge. Moreover, absorptive capacity as a path is dependent on the prior knowledge base of a firm. Zahra and George (2002) later proposed additional definitions that divide Cohen and Levinthal's definition of absorptive capacity into two main dimensions: potential absorptive capacity (the capabilities to acquire and assimilate knowledge) and realized absorptive capacity (the capabilities to transform and exploit knowledge) (Zahra \& George 2002). Many empirical studies have shown that there is a positive relationship between absorptive capacity and innovation. Pennings and Harianto's study (1992) showed that prior accumulated experience in a certain technological area increased the likelihood of innovation adoption. Becker and Peters (2000) and Nelson and Wolff (1997) argue that firms need higher absorptive capacities for scientific knowledge than for other types of knowledge. Tsai (2001) showed in his study that an organizational unit's absorptive capacity is positively related to its innovation activity, because 'organizational units with a high level of absorptive capacity are likely to harness new knowledge from other units to help their innovative activities'. Gao et al. (2008) show that firms with a higher absorptive capacity are more likely to innovate than those with a lower absorptive capacity. The above discussion makes it clear that absorptive capacity is strongly associated with innovative performance. We thus propose hypothesis 1 as:

The higher the levels of absorptive capacity, the higher the firm's innovation outcomes.

\subsection{Intended knowledge transfers as channels of external knowledge resources}

Firms establish linkages with other organizations with the intended purpose of accessing and acquiring different knowledge assets from external actors to develop their own technological innovations. A firm can interact with its partners on a formal basis. One of the common strategies is by means of formal collaborations, like joint R\&D, as effective ways of employing outside knowledge resources and increasing the effectiveness of innovations (Du \& Ai, 2008). The governance of this type of collaboration is most often 
through mutually-accepted contracts to control the relationship between the parties with the intention of increasing the level of success in the knowledge transfer process (Mentzas et al., 2006). Knowledge also can be transferred between organizations on a non-contractual basis by means of so-called informal networking activities which are conducted without any formal agreements between parties. Informal networks can be created by means of informal/social functions arranged between two organizations like breakfast/lunch meetings or golf events. Through these informal ties, the knowledge on how new products are created or other innovative ideas can be shared during social conversations.

Studies have shown the positive relationship between intended formal and informal interorganizational network activity and innovative performance. For example, a study by Berg Jensen, Johnson, Lorenz \& Lundvall (2007) shows that firms that applied a so-called Doing, Using and Interacting mode (informal processes of learning) in combination with a mode accessing and using codified knowledge, outperform firms relying predominantly on only one of the two modes. Boschma and Ter Walt (2007) reported that the strong local network position (a high number of formal inter-organizational relationships) of a firm tended to increase its innovative performance in an industrial district. It is through these intended interactions (i.e. ties in networks) that external knowledge is able to flow to an innovating firm. Intended knowledge transfers fuel innovations. Firms involved in interorganizational networks are able to gather more knowledge resources to perform their innovative activities. Partners with formalized relationships (e.g. through contracts) with a focal firm or those involved in informal relationships are more willing to share (and less likely to hold back) knowledge owing to the trust existing in these relationships. As a result, the receiver-firm is able to access better or more knowledge resources for successful innovations. Networks also provide opportunities for firms to compare and integrate intended knowledge flows from various sources so that new knowledge may emerge for technological development. Based on the above theoretical arguments, we propose hypothesis 2 :

The higher the number of intended knowledge transfer relationships, the higher the firm's innovation outcomes.

\subsection{Knowledge spillovers as external knowledge resources}

Knowledge spillovers (Fallah \& Ibrahim, 2004; Oerlemans \& Meeus, 2005; Erbas et al., 2008) can be defined as knowledge inflows resulting from deliberate search activities by innovating firms leading to an inflow of knowledge and information but without the consent of the owners of this knowledge and information. Firms without the knowledge necessary for developing competitive advantage can engage in such activities to reduce their knowledge disadvantage, for example, by 'hiring away well placed knowledgeable managers in a firm with a competitive advantage or by engaging in a careful systematic study of the other firm's success' (Barney, 2000: 214), by imitating other firms' technologies, or by monitoring other firms' innovative activities. Thus, knowledge spillovers 'denote the benefit of knowledge to firms not responsible for the original investment of the creation of this knowledge' (Almeida \& Kogut, 1999: 905). Previous researchers have attributed positive innovation effects to knowledge spillovers (Jaffe et al., 2000; Fallah \& Ibrahim, 2004; Oerlemans \& Meeus, 2005; Mukoyama, 2003). Learning from knowledge spillover has the same benefits as intended knowledge transfers, that is, there are more knowledge resources to perform innovative activities (Alcácer \& Chung, 2007). However, the main benefit of knowledge spillover is that relatively low costs are involved in acquiring such knowledge, in comparison with the high costs involved (e.g. contract costs) when a firm accesses intended knowledge transfers through formalized relationships or develops this knowledge internally. Hence, hypothesis 3 reads:

The higher the knowledge spillover, the higher a firm's innovation outcomes

\subsection{Science park location as external knowledge resources}

In the literature, science park location (SPL) is reported to have many value-added advantages 
for firms (Fukugawa, 2006). Science park firms are thought to have more networking opportunities with other resident firms on account of their geographical proximity. Besides this, which provides the possibility of face-to-face encounters, one of the tasks of a science park management team is to organize networking activities like seminars and social events amongst on-park firms as well as with organizations located outside the science park premises. Science park location therefore plays a role in facilitating knowledge transfer and innovative performance by firms, and can consequently be regarded as a (geographical) resource. Thus, hypothesis 4 reads:

Firms with a science park location have higher innovation outcomes in comparison with firms without science park location.

The above three hypotheses form the research model that this study will explore empirically. This research model is shown in the Figure 2:

Figure 2

Research model

\begin{tabular}{|c|c|c|}
\hline Absorptive capacity & $\mathrm{H} 1+$ & \multirow{5}{*}{ Innovation outcomes } \\
\hline Intended knowledge transfer & $\mathrm{H} 2+$ & \\
\hline & $\mathrm{H} 3+$ & \\
\hline & \multirow[t]{2}{*}{$\mathrm{H} 4+$} & \\
\hline Science park location & & \\
\hline
\end{tabular}

4

\section{Methods}

\subsection{Sample and data collection}

The focus of this study is the relationship between knowledge transfer relationships and multiple dimensions of innovation outcomes at the firm level. Units of analysis are NTBFs located in the Gauteng region of South Africa. On the one hand, Gauteng was chosen because it has one of the few well-functioning systems of innovation in South Africa (Lorentzen, 2009), whereas, on the other hand, variation due to geographical location is excluded, which is an advantage from the methodological point of view. The firms chosen for this study fulfill the criteria for NTBFs: small firm size (the number of employees, including directors/CEOs, is fewer than 50), a young firm age (fewer than 10 years since establishment) and highly technology-based (e.g. ICT, biotech, electronics industries). This research applies a quantitative research methodology. Data on the firms' knowledge transfer relationships and innovative performance were gathered by means of questionnaires sent to CEOs or directors of NTBFs. To ensure quality of feedback, most questionnaires were distributed personally, with short interviews to assist the completion of the questionnaires. A total of 52 valid questionnaires was returned, 24 of which came from NTBFs situated in The Innovation Hub (a science park) and 28 which came from independent NTBFs not located in a science park. The collected data were analyzed by applying multivariate regression analysis using SPSS software.

\subsection{Measurements of variables}

Table 1 lists the items used in the questionnaire to measure the variables proposed in the research framework. The items were based on measures proposed in the literature and a 5-point Likert-type scale was used. Table 2 shows the literature sourced when constructing our measurements, as well as the reliability statistics (Cronbach's alphas) of the scales used. Reliability tests were carried out for the independent variable 'knowledge spillovers' and the dependent variable 'relative innovative performance', which were measured using multiple items (both have six items using 5-point Likert scale). Cronbach's alphas of these two variables are 0.702 and 0.644 
respectively. Cronbach's alpha of 0.6 was used as a threshold value, which is sufficient for exploratory studies. These two variables can thus be measured with a single, unidimensional latent construct.

\subsubsection{Dependent variables}

In this study, we conceptualize innovation outcomes as a multi-dimensional construct. This study distinguishes various dimensions of innovation outcomes which are associated with various stages of the innovation model: (1) Number of patents; (2) Number of new products/services developed but not yet introduced into the market; (3) Scope of innovation results; (4) Innovation sales from improved products/services; (5) Innovation sales from products/services new to the firm (see Figure 1). The first type of innovation outcome (patents) is associated with the two initial stages of the innovation process, basic research and invention.

Table 1

Item(s) of variables and their sources

\begin{tabular}{|c|c|c|}
\hline \multicolumn{2}{|c|}{ Independent variables } & Item(s) \\
\hline \multicolumn{2}{|c|}{ Absorptive capacity } & $\begin{array}{l}\text { Indicate level of agreement with the following statements: (1) Most of our staff are highly } \\
\text { skilled and qualified; (2) We invest a great deal in training; (3) We innovate by improving } \\
\text { competitors' products and processes; (4) Most of the time we are ahead of our } \\
\text { competitors in developing and launching new products; (5) We have the capacity to } \\
\text { adapt others' technologies; (6) We innovate as a result of R\&D carried out within our } \\
\text { own firm; (7) We have considerable resources and own knowledge resources for } \\
\text { technological development; (8) We are able to introduce into the market innovations } \\
\text { which are completely novel on a worldwide scale. } \\
\text { ( } 5 \text { points Likert scale: } 1 \text { = strongly disagree, } 3 \text { = neither agree nor disagree, } \\
5=\text { strongly agree) }\end{array}$ \\
\hline \multirow{2}{*}{$\begin{array}{l}\text { Intended } \\
\text { knowledge } \\
\text { transfers (Otte } \\
\text { \& Rousseau, } \\
\text { 2002) }\end{array}$} & $\begin{array}{l}\text { Formal } \\
\text { relationships }\end{array}$ & $\begin{array}{l}\text { Number of organizations (suppliers, buyers, consultants, competitors, universities, public } \\
\text { labs and sector institutes) with which the respondent firm has formal/contractual } \\
\text { agreements to acquire knowledge. }\end{array}$ \\
\hline & $\begin{array}{l}\text { Informal } \\
\text { relationships }\end{array}$ & $\begin{array}{l}\text { Number of organizations (suppliers, buyers, consultants, competitors, universities, public } \\
\text { labs and sector institutes) with which the respondent firm interacts on a non-contractual } \\
\text { basis (i.e. informal, social basis) to acquire knowledge. }\end{array}$ \\
\hline \multicolumn{2}{|c|}{$\begin{array}{l}\text { Knowledge spillovers } \\
\text { (Howells, 2002) }\end{array}$} & $\begin{array}{l}\text { How often does your firm use the following sources from other organizations/actors to } \\
\text { acquire knowledge for your firm's innovations? } \\
\text { (1) employing key scientists and engineers (including poaching key staff); } \\
\text { (2) acquiring key information at conferences and workshops; (3) reverse engineering of } \\
\text { technological knowledge embedded in products developed/produced by other } \\
\text { firms/organizations; (4) accessing patent information filed by other firms/organizations; } \\
\text { (5) knowledge embedded in organizational processes or routines of other } \\
\text { firms/organizations; (6) publications in technical and scientific papers by other } \\
\text { firms/organizations. } \\
\text { (5 point Likert scale: never, rarely, sometimes, regularly or always; } \alpha=0.702)\end{array}$ \\
\hline \multicolumn{2}{|l|}{ SP location } & Is the firm located in The Innovation Hub $(y / n) ?$ \\
\hline \multicolumn{2}{|c|}{ Dependent Variable } & Item(s) \\
\hline \multicolumn{2}{|c|}{$\begin{array}{l}\text { Firm's innovation outcomes } \\
\text { Sales items (Laursen \& Salter, } \\
2006 \text { ) } \\
\text { Scope item (Oerlemans \& } \\
\text { Meeus, 2005) }\end{array}$} & $\begin{array}{l}\text { Five indicators of innovation outcomes were used: } \\
\text { 1. Patents: Did the firm file patents in } 2007 \text { ? (yes/no) } \\
\text { 2. Developed products/services: Did the firm develop new products/services but has not } \\
\text { yet introduced them into the market in } 2007 \text { ? (yes/no) } \\
\text { 3. Incremental innovative sales: The percentage of sales of products/services that were } \\
\text { technologically improved to the firm in } 2007 \\
\text { 4. New innovative sales: The percentage of sales of products/services that were } \\
\text { developed using technologies new to the firm in } 2007 \text {. } \\
\text { 5. Scope of innovation outcomes: the technical performance due to innovations. } \\
\text { For the last item, the following question was asked: } \\
\text { To what extent did your firm's product and/or service innovations result in: } \\
\text { (a) reduction of development and maintenance costs; (b) quality improvement of } \\
\text { products and/or services; (c) increase in production capacity; (d) improvement in delivery } \\
\text { times. } \\
(5 \text { points Likert scale: } 1=\text { very little, } 3=\text { not little / not much, } 5=\text { very much; } \\
\text { (a=0.656)). }\end{array}$ \\
\hline \multicolumn{2}{|c|}{ Control variables } & Item(s) \\
\hline \multicolumn{2}{|l|}{ Firm age } & Number of years the firm has existed. \\
\hline \multicolumn{2}{|l|}{ Firm size } & Total number of employees including the CEOs and directors in 2007. \\
\hline
\end{tabular}


The second and third types of innovation outcome are the development of new products or services and the scope of innovation outcomes (Oerlemans \& Meeus, 2005). The latter outcome variable is a qualitative dimension indicating that "part of the innovative efforts of firms are directed at, for example, a reduction of cost prices, quality improvements or the speeding up of internal processes' (Oerlemans \& Meeus, 2005: 96). The last two outcome variables are innovative sales (Laursen \& Salter, 2006) which capture the commercial performance of innovations expressed as the percentage of sales of new or improved products and services. This outcome indicator was first introduced into the European Community Innovation Survey. In the questionnaire used for this research, 'technologically new or improved innovation' means that fundamental characteristics of products or services are new or significantly improved in relation to the essential characteristics of comparable earlier services or products. There should be a wider range of use for the client and/or the relevant technical product specifications should show significant improvements in comparison with the specifications of earlier versions.

These outcomes are innovation outcome measures associated with the commercialization stage (production, marketing and sales) of the innovation process. To conclude, the indicators used in this study as indicators of innovation outcomes are illustrated in Table 1.

\subsubsection{Independent and control variables}

This study distinguishes between 'intended knowledge transfers' and 'knowledge spillovers' as specifications of the general concept of 'knowledge transfers'. Intended knowledge transfers are measured by taking two types of knowledge relationships into account: after all, a firm can acquire intended knowledge by means of both formal and informal relationships.

Knowledge spillovers are observed by the firm's 'imitative' or 'opportunistic' behaviour, such as 'reverse engineering' or 'monitor other firms' innovative activities'.
The third independent variable is science park location (yes/no). Out of the 52 NTBFs we surveyed, 24 firms are situated in The Innovation Hub, which is the first internationally accredited science park in South Africa.

The recipient's firm age and firm size are included as control variables. We controlled for these, given that these two firm attributes have been important factors for the propensity of firms to acquire and exploit knowledge resources (e.g. Bresman et al., 1999; Agarwal \& Gort, 2002; Cavusgil et al., 2003). Smaller and younger firms often face significant risk and uncertainty owing to lack of knowledge resources (liability of newness).

\section{5}

\section{Empirical results}

\subsection{Descriptive statistics}

Means and standard deviations associated with the variables under study are presented in Table 2. The mean scores for all eight items of absorptive capacity are above the mid-point of 3 (on a scale of 1 to 5); this shows that firms possess an above-satisfactory level of absorptive capacity. On average, NTBFs access intended knowledge from about 10 partners formally and about 37 partners informally. The average of the knowledge spillover score is close to 1.5 on a scale of 5 , showing that, on average, NTBFs "rarely" to "sometimes" search in this mode. About 46 per cent of the firms in the sample are located in a science park location. NTBFs report that, on average, 42.12 per cent of their sales come from innovated products and services which are technologically improved to the firm, whereas about 30 per cent of sales were generated with products or services that were technologically new to the firm. The average score for the scope of innovation outcomes (i.e. technical performance owing to innovations) is 3.68 , indicating a relatively high level. The averages of firm age and size are 5.13 years and 9.25 employees respectively. This shows that the sample firms are young and small. 
Table 2

Means and standard deviations

\begin{tabular}{|c|c|c|}
\hline Variables & Mean & Std. dev. \\
\hline \multicolumn{3}{|l|}{ Independent variables: } \\
\hline Absorptive capacity item 1 & 4.23 & 0.899 \\
\hline Absorptive capacity item 2 & 3.31 & 1.213 \\
\hline Absorptive capacity item 3 & 3.06 & 1.290 \\
\hline Absorptive capacity item 4 & 3.73 & 1.012 \\
\hline Absorptive capacity item 5 & 3.94 & 0.802 \\
\hline Absorptive capacity item 6 & 3.87 & 1.205 \\
\hline Absorptive capacity item 7 & 3.60 & 1.107 \\
\hline Absorptive capacity item 8 & 3.73 & 1.206 \\
\hline Intended knowledge transfer through formal relationships (number) & 9.75 & 12.516 \\
\hline Intended knowledge transfer through informal relationships (number) & 37.49 & 39.45 \\
\hline Knowledge spillovers (KS) & 1.519 & 0.671 \\
\hline SP location (SPL) & 0.46 & 0.50 \\
\hline \multicolumn{3}{|l|}{ Dependent variables: Innovation outcomes } \\
\hline Patents filed in 2007 & 0.135 & 0.345 \\
\hline Developed products/services not yet on the market (2007) & 0.558 & 0.501 \\
\hline Innovative sales improved to the firm & 42.12 & 35.81 \\
\hline Innovative sales new to the firm & 30.10 & 30.33 \\
\hline Scope of innovation outcomes & 3.572 & 0.809 \\
\hline \multicolumn{3}{|l|}{ Control variables } \\
\hline Firm age & 5.13 & 3.61 \\
\hline Firm size & 9.25 & 9.91 \\
\hline
\end{tabular}

The items of 'absorptive capacity' were entered in a principal component factor analysis that produces a two-factor solution $(\mathrm{KMO}=0.655$; Bartlett $=70.411 ; p=0.000)$. Table 3 shows that absorptive capacity items 3 , 2 and 5 loaded onto a factor that can be named 'absorptive capacity for incremental innovations'; whereas the second factor containing items 1, 6, 7 and 8 can be labeled 'absorptive capacity for new innovations'. Note that item 6 is not loading onto any of the two factors and is therefore excluded.

\section{Table 3}

Factor analysis for absorptive capacity

\begin{tabular}{|l|c|}
\hline \multicolumn{1}{|c|}{ Independent variable } & \multicolumn{1}{|c|}{ Component } \\
\hline $\begin{array}{l}\text { Absorptive capacity for incremental innovations (ACII): } \\
\text { Item 2: Our firm invests substantially in training. }\end{array}$ & $\mathbf{1}$ \\
\hline Item 3: Our firm innovates by improving other firms' products and processes. & 0.722 \\
Item 5: Our firm has the ability to adapt other firms' technologies. & 0.762 \\
\hline $\begin{array}{l}\text { Absorptive capacity for new innovations (ACNI): } \\
\text { Item 1: Most of the staff in our firm are highly skilled and qualified. }\end{array}$ & 0.703 \\
Item 6: Our firm innovates as a result of its own R\&D. & 0.500 \\
Item 7: Our firm has considerable resources and own knowledge resources for technological & 0.809 \\
\hline $\begin{array}{l}\text { Item 8: Our firm is able to introduce into the market innovations which are completely } \\
\quad \text { novel on a worldwide scale. }\end{array}$ & 0.532 \\
\hline
\end{tabular}

\subsection{Multivariate regression analysis}

With the five dimensions of innovation outcomes as dependent variables, as well as two types of intended knowledge transfers (formal and informal ties), a total of 10 models was estimated. The models in this study are estimated by using SPSS to perform binominal logistic regression analyses for the first four models and ordinary Least Square-based Regression analyses for the next six models. 


\subsubsection{Innovation outcomes: patents and developed products/services not yet on the market}

If patents filed in 2007 are used as the dependent variable, it turns out that, with the exception of knowledge spillovers in the model for informal ties, none of the independent variables plays a statistically significant role. This model shows that a more frequent use of the knowledge spillover mechanism is associated with a higher probability of filing a patent. Additional analyses revealed that firms filing a patent accessed the patents and scientific publications of other organizations. This indicates an imitative mode of innovation. Moreover, it is interesting to see that, in the (science park) literature, knowledge transfers are often regarded as generating patents, but this is apparently not really the case here. This finding may be explained by what was found in interviews conducted among sample firms who expressed their reluctance to file patents because of the cost of doing so. In addition, it was expected that the firms with a science park location perform innovative activities and therefore would have filed patents. This was generally not the case in the South African context.

For the second innovation output discerned, "developed products/services not introduced in the market yet", also knowledge spillovers play a positive and significant role. At the firm level, knowledge spillovers are associated with opportunistic behaviours such as imitation, which seems to be displayed by South African firms. Firms imitate with the intention of improving the features of their already-existing technologies. In the case of South Africa, it seems that firms gain benefits from knowledge spillovers during the early stage of the innovation model when developments take place.

Table 4

Results of binominal logistic regression analysis $(\mathrm{N}=52)$

\begin{tabular}{|c|c|c|c|c|}
\hline \multirow{3}{*}{ Variable } & \multicolumn{4}{|c|}{ Dimension of innovation outcomes } \\
\hline & \multicolumn{2}{|c|}{ Patents filed in 2007? } & \multicolumn{2}{|c|}{$\begin{array}{l}\text { Developed products/services but not yet } \\
\text { introduced on market in 2007? }\end{array}$} \\
\hline & IKT = Formal ties & IKT = Informal ties & IKT = Formal ties & IKT = Informal ties \\
\hline $\begin{array}{l}\text { Constant } \\
\text { Age } \\
\text { Size } \\
\text { ACII } \\
\text { ACNI } \\
\text { IKT } \\
\text { KS } \\
\text { SPL }\end{array}$ & $\begin{array}{l}0.06^{*} \\
0.93 \\
0.97 \\
0.81 \\
0.73 \\
1.21 \\
3.56 \\
0.24\end{array}$ & $\begin{array}{l}0.05^{\star} \\
0.97 \\
1.12 \\
0.98 \\
0.70 \\
0.99 \\
5.85^{\star} \\
0.31\end{array}$ & $\begin{array}{l}1.14 \\
0.89 \\
0.69 \\
1.01 \\
1.63 \\
1.04 \\
4.56^{*} \\
0.39\end{array}$ & $\begin{array}{l}0.95 \\
0.96 \\
0.72 \\
1.18 \\
1.67 \\
1.00 \\
4.88^{*} \\
0.37\end{array}$ \\
\hline $\begin{array}{l}\text { N. } R^{2} \\
\text { HL-test }\end{array}$ & $\begin{array}{r}15.6 \% \\
0.053\end{array}$ & $\begin{array}{r}16.3 \% \\
0.223\end{array}$ & $\begin{array}{r}28.0 \% \\
0.845\end{array}$ & $\begin{array}{r}26.4 \% \\
0.355\end{array}$ \\
\hline
\end{tabular}

\subsubsection{Innovation outcomes: scope of innovation and innovative sales}

When it comes to the scope of innovation outcomes, none of the external knowledge resources from either formal or informal ties has statistically significant impacts. This implies that none of the variables indicating the inter-organizational network activity of these types impacts on this dimension of innovation outcome. On the other hand, the absorptive capacity for incremental innovations (ACII) has a positive and significant impact. Thus hypothesis 1 is partially supported.

For the models in which innovation sales from improved products/services are the dependent variable, none of the variables in the two models has statistically significant F-values $(\mathrm{p}<0.1)$, which means that the estimated regression models do not fit the data. It is interesting to observe that the absorptive capacity for incremental innovations has no impact on sales of products or services that are technologically improved (i.e. incremental 
innovations). As far as the knowledge transfer variables are concerned, neither intended knowledge transfers nor knowledge spillovers have any impact on this dependent variable. Moreover, science park location does not play a role in incremental innovation outcome. Overall, regarding this type of outcome, it can be concluded that none of the hypotheses are confirmed.

The results of regression analyses for the innovation outcome indicator 'innovative sales new to the firm' are shown in the last two models in Table 5. Only the last model with knowledge transfers via informal ties is statistically significant (F-value $p<0.1$ ). In this model, a higher number of informal knowledge transfer relationships results in a lower level of sales of technologically new product/service innovations. Thus hypothesis 2 is rejected for informal knowledge transfer relationships. On the other hand, the other two external knowledge resources (knowledge spillovers and SPL) have positive and significant impacts on the innovation outcome of this type. Consequently hypotheses 3 and 4 are confirmed for these resources.

\section{Table 5}

Results of OLS regression analysis $(\mathrm{N}=52)$

\begin{tabular}{|c|c|c|c|c|c|c|}
\hline \multirow{3}{*}{ Variable } & \multicolumn{6}{|c|}{ Dimension of innovation outcomes } \\
\hline & \multicolumn{2}{|c|}{ Scope of innovation outcomes } & \multicolumn{2}{|c|}{$\begin{array}{c}\text { Innovation sales } \\
\text { technologically improved } \\
\text { products/services }\end{array}$} & \multicolumn{2}{|c|}{$\begin{array}{l}\text { Innovation sales } \\
\text { technologically new } \\
\text { products/services }\end{array}$} \\
\hline & $\begin{array}{c}\text { IKT = Formal } \\
\text { ties }\end{array}$ & $\begin{array}{c}\text { IKT = Informal } \\
\text { ties }\end{array}$ & $\begin{array}{c}\text { IKT = Formal } \\
\text { ties }\end{array}$ & $\begin{array}{c}\text { IKT = Informal } \\
\text { ties }\end{array}$ & $\begin{array}{c}\text { IKT = Formal } \\
\text { ties }\end{array}$ & $\begin{array}{c}\mathrm{IKT}=\underset{\text { Iies }}{\text { Informal }} \\
\text { ties }\end{array}$ \\
\hline $\begin{array}{l}\text { Constant } \\
\text { Age } \\
\text { Size } \\
\text { ACII } \\
\text { ACNI } \\
\text { IKT } \\
\text { KS } \\
\text { SPL }\end{array}$ & $\begin{array}{l}3.63^{\star \star \star} \\
0.20 \\
-0.34^{\star} \\
0.33^{\star} \\
0.07 \\
0.29 \\
-0.13 \\
0.14\end{array}$ & $\begin{array}{l}3.54^{\star \star \star} \\
0.22 \\
-0.12 \\
0.39^{\star \star} \\
0.16 \\
0.21 \\
-0.16 \\
0.14\end{array}$ & $\begin{array}{r}37.2^{\star *} \\
0.12 \\
0.08 \\
0.21 \\
0.10 \\
-0.02 \\
-0.14 \\
0.13\end{array}$ & $\begin{array}{r}36.6^{\star *} \\
0.06 \\
0.13 \\
0.16 \\
0.15 \\
0.22 \\
-0.24 \\
0.10\end{array}$ & $\begin{array}{l}32.9^{* *} \\
-0.07 \\
-0.31^{* *} \\
-0.12 \\
-0.11 \\
0.09 \\
0.14 \\
0.22\end{array}$ & $\begin{array}{c}26.1^{*} \\
0.01 \\
-0.24 \\
0.01 \\
-0.15 \\
-0.37^{\star *} \\
0.35^{\star *} \\
0.30^{* *}\end{array}$ \\
\hline $\begin{array}{l}\mathrm{R}^{2} \\
\text { F-value } \\
\text { VIFs }\end{array}$ & $\begin{array}{c}28.0 \% \\
2.06^{*} \\
1.08-2.06\end{array}$ & $\begin{array}{c}27.4 \% \\
1.94^{*} \\
1.17-1.76\end{array}$ & $\begin{array}{c}10.7 \% \\
0.75 \\
1.01-1.97\end{array}$ & $\begin{array}{c}15.9 \% \\
1.16 \\
1.04-1.65\end{array}$ & $\begin{array}{c}19.4 \% \\
1.52 \\
1.01-1.97\end{array}$ & $\begin{array}{c}26.8 \% \\
2.25^{\star *} \\
1.04-1.65\end{array}$ \\
\hline
\end{tabular}

\section{6}

\section{Conclusions and discussion}

\subsection{Findings and implications}

The primary objective of this study was to investigate the effects of internal knowledge resources (in terms of absorptive capacities) and external knowledge resources (in terms of knowledge transfers and science park location) on a variety of innovation outcomes that are associated with the various stages of a firm's innovation process. The study set out to answer the research question: Does the use of different innovation outcomes indicators explain the mixed findings reported in the literature? Based on a review of the literature, four hypotheses were formulated.

In the empirical section of the paper, a sample of NTBFs located in the Gauteng region, which is the economic engine of South Africa, was used. Data was collected during the firm-level by means of structured interviews with questionnaires targeted at the directors or CEOs: 52 valid questionnaires were obtained and about 50 per cent of these firms were located in a science park. Statistical analysis using multivariate regression models presents several interesting findings, which will be discussed below.

We start our discussion on the findings of this study with the observation that a generally accepted model of knowledge production produces non-consistent and non-systematic results across different dimensions of innovation outcomes. The implication is that it makes sense to distinguish multiple indicators of innovation outcomes referring to different 
phases in a firm's innovation process. A very clear example of this is the variable "number of informal ties", which has no impact on the probability that a firm has a product or service innovation that has not yet been introduced into the market, but has a negative impact on the sales generated by technologically new products or services. We therefore advise scholars researching the performance of science park firms to start their empirical research from a broad conceptualization of innovation outcomes and not to focus on just one outcome dimension, which is often the case in current research.

A second highly interesting finding is that the models perform poorly when outcome measures that reflect outcomes in the early phases of the innovation process are used, whereas the innovation sales indicator, which is a measure related to the commercialization stage of innovations, produces much better results. Many science parks are established by policy-makers and regional actors to increase inventions and innovations, which would become visible with higher numbers of patents or newly-developed products and services. This does not seem to be case in the South African context. As the results show, these science park firms are able to market their product and service innovations, but such a location seems not to matter for early stage innovation outcomes. How are these results to be interpreted? One interpretation is that this science park and its firms are doing a good job, as they seem to be able to generate economic value from their innovations. After all, in the past these product and service innovations could have been related to a patent or were not yet introduced on a market. Such results would be pleasing to policy-makers because generating economic value is exactly the aim of many parks.

However, the question is how sustainable these innovation outcomes are. A critical look at the findings reveals, on the one hand, that intended knowledge transfers lower innovation sales outcomes. This is a very unusual finding, because the vast majority of other studies point in exactly the opposite direction (Cassiman \& Veugelers, 2006; Ahuja, 2000). One explanation of this counterintuitive result lies in the way in which these independent variables were measured. All intended knowledge transfers were measured using degree centrality, that is, the number of formal or informal ties with external actors. Informal relationships are often maintained with actors who are very similar. This so-called homophily effect (McPherson et al., 2001) in networks has a negative effect on innovation because similar actors have similar knowledge. Maurer and Ebers (2006) found that too many relationships with similar actors may result in relational lock-in, which contributes to inertia in social capital and the concomitant negative impact on firm performance. An alternative explanation is related to the quantity and quality of the knowledge and information acquired through informal relationships. As demonstrated here, the NTBFs in our sample hold many informal ties, which could lead to information overload, whereas at the same time the knowledge possessed by these external social actors is not necessarily the most relevant from the business perspective.

On the other hand, it is found that knowledge spillovers (often a result of opportunistic behavior) are important to innovation outcomes in the South African context. This corresponds to findings in a study by Oerlemans and Pretorius (2006) in which they reported that South African firms tended to be imitative by nature. This is not necessarily a bad thing in an economy that lacks all kinds of (knowledge) resources. As Yamamura, Sonobe and Otsuka (2005) show for the Japanese motorcycle industry, an imitation strategy can be beneficial in the early growth stages of firms and industries. This concurs partly with the finding in a study by Aghion et al. (2001), who show that a little imitation enhances economic growth owing to increased neck-and-neck competition. However, they point out that excessive imitation is growth-reducing. All in all, it could be concluded that this imitation strategy is not viable in the long run.

The findings of this research have important implications for managerial practice at different levels. At the firm level, managers of science park firms could reconsider the composition of their network of relations by decreasing the number of informal ties, because there is strong evidence that too many 
informal ties reduce innovation outcomes. A second recommendation could be to reconsider the imitation innovation strategy. The own or co-development of improved or new products would, in the long run, lead to a more competitive and successful business community in South Africa.

At the level of science park management, taking a critical look at the activities and composition of firms located in science parks is also a recommendation. Although the commercialization of innovative products and services is certainly an important dimension of the performance of science parks, it is also important to have firms that are in the early stages of the innovation process, so focusing more on knowledge development becomes a further consideration.

\subsection{Limitations and direction for future research}

Although this study reveals valuable insights into the relationship between absorptive capacity, intended inter-organizational knowledge transfers, knowledge spillovers, science park location, and a variety of innovation outcomes at the firm level, some limitations remain. First, these findings are limited to a population of small technology-based firms in South Africa. It is therefore worthwhile to examine the relationships proposed in this paper in other contexts. Second, the dependent variable in the models (innovation outcomes) does not take process innovations into account. However, from the preliminary data analysis, the business and innovation activities of most firms in the sample are not focused on process development, but more focused on products/services development. Thus, although the results of this study do not give a complete picture of technological innovation in NTBFs, they are still valid in the South African context. Third, although this research took a differentiated approach by distinguishing between formal and informal knowledge transfer relationships, only the number of direct ties was taken into account. This is a commonly accepted approach in the field (Ahuja, 2000), but it implies that other relevant aspects of inter-organizational knowledge transfer relations are not included in the models. Examples are the strength of ties (Gilsing \& Nooteboom, 2005) or the characteristics of partners in the networks (Tether, 2002).

This research raises a number of directions for future research. First, moderator variables may be explored to further examine which factors may have an influence on the relationship between intended knowledge transfers and knowledge spillovers on the one hand, and innovative performance on the other. An example could be the type of partner because the probability of knowledge spillover is higher when the collaborative partner is, for example, a competitor (Hamel, 1991). Second, this research has been performed in an emerging economy. Similar studies could be conducted in other countries with emerging economies to benchmark the results of this research. Third, as mentioned earlier in the limitations of this study, other aspects of network characteristics could be included in future studies. For example, knowledge from networks established with 'technologically similar' partners may enhance incremental innovations, whereas with partners who have totally different technologies (e.g. ICT versus biotech), radical innovations may open up an entirely new market (Laursen \& Salter, 2006).

\section{Endnotes}

1 Due to page constraints, the summary table is not included in this paper. Details of this literature review and the summary table can be acquired by contacting the authors.

2 The authors are aware that the innovation process is of a non-sequential nature and has feedback loops. The reason for this linear and simplified model is to show that various stages are linked with various innovation outcomes.

\section{Acknowledgement}

We would like to thank the two anonymous reviewers for their valuable comments. All remaining errors are our responsibility. 


\section{References}

ACS, Z.J., AUDRETSCH, D.B. \& FELDMAN, M.P. 1994. R\&D spillovers and recipient firm size. Review of Economics and Statistics, 76 (2):336-340.

AGHION, P., HARRIS, C., HOWITT, P. \& VICKERS, J. 2001. Competition, imitation and growth with step-by-step innovation. Review of Economic Studies, 68(3):467-492.

AGARWAL, R. \& GORT, M. 2002. Firm and product life cycles and firm survival. The American Economic Review, 92 (2):184-190.

AHUJA, G. 2000. Collaboration networks, structural holes and innovation: a longitudinal study. Administrative Science Quarterly, 45(3):425-455.

AKÇOMAK, I. S. \& TAYMAZ, E. 2004. Assessing the effectiveness of incubators: the case of Turkey. ERC Working Papers 0412, ERC - Economic Research Center, Middle East Technical University.

ALCÁCER, J. \& CHUNG, W. 2007. Location strategies and knowledge spillovers. Management Science, 53(5):760-776

ALMEIDA, P. \& KOGUT, B. 1999. Localisation of knowledge and the mobility of engineers in regional networks. Management Science, 45(7):905-917.

BAKOUROS, Y.L., MARDAS, D.C. \& VARSAKELIS, N.C. 2002. Science park, a high tech fantasy? An analysis of the science parks of Greece. Technovation, 22(2):123-128.

BARNEY, J.B. 2000. Firm resources and sustained competitive advantage. Advances in Strategic Management, 17:203-227.

BECKER, W. \& PETERS, J. 2000. Technological opportunities, absorptive capacities, and innovation. Augsburg: Volkswirtschaftliche Diskussionsreihe.

BERG JENSEN, M., JOHNSON, B., LORENZ, E. \& LUNDVALL, B-A. 2007. Forms of knowledge and modes of innovation. Research Policy, 36(5):680-693.

BOSCHMA, R.A. \& TER WAL, A.L.J. 2007. Knowledge networks and innovative performance in an industrial district: The case of a footwear district in the South of Italy. Industry and Innovation, 14(2): 177-199.

BOTTAZZI, L. \& GIOVANNI, P. 2003. Innovation and spillovers in regions: evidence from the European patent data. European Economic Review, 47:687-710.

BRESMAN, H., BIRKINSHAW, J.M., NOBEL, R. 1999. Knowledge transfer in international acquisitions. Journal of International Business Studies, 30(3):439-462.

CASSIMAN, B. \& VEUGELERS, R. 2006. In search of complementarity in innovation strategy: internal R\&D and external knowledge acquisition. Management Science, 52(1):68-82.

CAVUSGIL, S.T., CALANTONE R.J. \& ZHAO, Y. 2003. Tacit knowledge transfer and firm innovation capability. Journal of Business \& Industrial Marketing, 18(1):6-21.

CHEN, S. \& CHOI, C.J. 2004. Creating a knowledge-based city: the example of Hsinchu Science Park. Journal of Knowledge Management, 8(5):73-82.

COHEN, W. \& LEVINTHAL, D. 1990. Absorptive capacity: a new perspective on learning and innovation. Administrative Science Quarterly, 35(1):128-152.

COLOMBO, M.G. \& DELMASTRO, M. 2002. How effective are technology incubators? Evidence from Italy. Research Policy, 31(7):1103-1122.

DETTWILER, P., LINDELÖF, P. \& LÖFSTEN, H. 2006. Utility of location: a comparative survey between small new technology-based firms located on and off science parks: Implications for facilities management. Technovation, 26(4):506-517.

DU, R. \& AI, S. 2008. Cross-organizational knowledge acquisition through flexible hiring and joint R\&D: insights from a survey in China. Expert Systems with Applications, 35(1-2):434-441.

ERBAS, B.C., FIKIRKOCA, A. \& TUZCU, A. 2008. Innovativeness of manufacturing small and medium size enterprises in Turkish regional innovation system. Paper presented at Regional Studies Association $12^{\text {th }}$ Annual International Conference, Prague, Czech Republic, May.

ERNST, H. 2001. Patent applications and subsequent changes of performance: evidence from time-series cross-section analyses on the firm level. Research Policy, 30:143-157. 
ETZKOWITZ, H. \& LEYDESDORFF, L. 2000. The dynamics of innovation: from National Systems and 'mode 2' to a Triple Helix of university-industry-government relations. Research Policy, 29(2):109-123.

FALLAH, M.H. \& IBRAHIM, S. 2004. Knowledge spillover and innovation in technological clusters, paper presented at International Association for Management of Technology $13^{\text {th }}$ International Conference on Management of Technology, Washington D.C., United States of America, April.

FELDMAN, M.P. 1994. The geography of innovation. Dordrecht: Kluwer Academic Publishers.

FELSENSTEIN, D. 1994. University-related science parks: 'seedbeds' or 'enclaves' of innovation? Technovation, 14(2):93-110.

FERGUSON, R. \& OLOFSSON, C. 2004. Science parks and the development of NTBFs: Location, survival and growth. Journal of Technology Transfer, 29(1):5-17.

FUKUGAWA, N. 2006. Science parks in Japan and their value-added contributions to new technology-based firms. International Journal of Industrial Organization, 24(2):381-400.

GAO, S., XU, K. \& YANG, J. 2008. Managerial ties, absorptive capacity, and innovation. Asia Pacific Journal of Management, 25:395-412.

GILSING, V. \& NOOTEBOOM, B. 2005. Density and strength of ties in innovation networks: an analysis of multimedia and biotechnology. European Management Review, 2(3):179-197.

GREEN, E.G.T., DESCHAMPS, J. \& PÁEZ, D. 2005. Variation of individualism and collectivism within and between twenty countries: a typological analysis. Journal of Cross-cultural Psychology, 36(3):321-339.

HALL, B.H. \& MAIRESSE, J. 2006. Empirical studies of innovation in the knowledge driven economy. Economics of Innovation and New Technology, 15:289-299.

HAMEL, G. 1991. Competition for competence and inter-partner learning within international strategic alliances. Strategic Management Journal, 12 (special issue):83-103.

HOWELLS, J.R.L. 2002. Tacit knowledge, innovation and economic geography. Urban Studies, 39(5): 871-884.

INTERNATIONAL ASSOCIATION OF SCIENCE PARKS (IASP). Available at: URL: http://www.iasp.ws [Accessed 2007-07-011].

ICHIJO, K. \& NONAKA, I. 2007. Introduction: knowledge as competitive advantage in the age of increasing globalization. In Ichijo, K. \& Nonaka, I. (eds.) Knowledge creation and management: new challenges for managers. New York: Oxford University Press.

JAFFE, A.B., TRAJTENBERG, M. \& FOGARTY, M.R. 2000. Knowledge spillovers and patent citations: Evidence from a survey of inventors. American Economic Review, 9(2):215-19.

KHILJI, S.E., MROCZKOWSKI, T. \& BERSTEIN, B. 2006. From invention to innovation: Toward developing an integrated innovation model for biotech firms. Journal of Product Innovation Management, 23 (6):528-540.

KNOBEN, J. \& OERLEMANS, L.A.G. 2006. Proximity and inter-organizational collaboration: a literature review. International Journal of Management Reviews, 8(2):71-89.

LAURSEN, K. \& SALTER, A. 2006. Open for innovation: the role of openness in explaining innovation performance among U.K. manufacturing firms. Strategic Management Journal, 27(2):131-150.

LINDELÖF, P \& LÖFSTEN, H. 2003. Science park location and new technology-based firms in Sweden: implications for strategy and performance. Small Business Economics, 20(3):245-258.

LINDELÖF, P \& LÖFSTEN, H. 2004. Proximity as a resource base for competitive advantage: universityindustry links for technology transfer. Journal of Technology Transfer, 29(3-4):311-326.

LÖFSTEN, H. \& LINDELÖF, P. 2002. Science parks and the growth of new technology-based firms: academic-industry links, innovation and markets. Research Policy, 31(6):859-876.

LORENTZEN, J. 2009. Learning by firms: the black box of South Africa's innovation systems. Science and Public Policy, 36(1):33-45.

MALAIRAJA, C. \& ZAWDIE, G. 2008. Science parks and university-industry collaboration in Malaysia. Technology Analysis and Strategic Management, 20(6):727-739.

MASSEY, D., QUINTAS, P. \& WIELD, D.1992. High tech fantasies: science parks in society, science and space. London: Routledge.

MAURER, I. \& EBERS, M. 2006. Dynamics of social capital and their performance implications: lessons from biotechnology start-ups. Administrative Science Quarterly, 51(2):262-292. 
MENTZAS, G., APOSTOLOU, D., KAFENTZIS, K. \& GEORGOLIOS, P. 2006. Inter-organizational networks for knowledge sharing and trading. Information Technology and Management, 7(4):259-276. MCADAM, M. \& MCADAM, R. 2008. High tech start-ups in university science park incubators: the relationship between the start-up's lifecycle progression and the use of the incubator's resources. Technovation, 28(5):277-290.

MCPHERSON, M., SMITH-LOVIN, L. \& COOK, J.M. 2001. Birds of a feather: homophily in social networks. Annual Review of Sociology, 27:415-444.

MITCHELL, B.C. \& CO, M.J. 2004. Entrepreneurial networks: findings from a South African study. South African Journal of Economics and Management Sciences, 7(4):589-600.

MUKOYAMA, T. 2003. Innovation, imitation, and growth with cumulative technology. Journal of Monetary Economics, 50(2):361-380.

MURMANN, J.P. 2003. Knowledge and competitive advantage. Cambridge: Cambridge University Press. NELSON, R. \& WOLFF, E.N. 1997. Factors behind cross-industry differences in technological progress. Structural Change and Economic Dynamics, 8:205-220.

OERLEMANS, L.A.G. \& MEEUS, M.T.H. 2005. Do organizational and spatial proximity impact on firm performance? Regional Studies, 39:89-104.

OERLEMANS, L.A.G. \& PRETORIUS, M.W. 2006. Some views on determinants of innovative outcomes of South African firms: An exploratory analysis using firm-level data. South African Journal of Science, 102(11/12):589-593.

OTTE, E. \& ROUSSEAU, R. 2002. Social network analysis: a powerful strategy, also for the information sciences. Journal of Information Science, 28:443-455.

PENNINGS, J.M. \& HARIANTO, F. 1992. The diffusion of technological innovation in the commercial banking industry. Strategic Management Journal, 13(1):29-46.

ROPER, S., DU, J. \& LOVE, J.H. 2008. Modelling the innovation value chain. Research Policy, 37:961-977.

SIEGEL, D.S., WESTHEAD, P. \& WRIGHT, M. 2003. Assessing the impact of university science parks on research productivity: exploratory firm-level evidence from the United Kingdom. International Journal of Industrial Organization, 21(9):1357-1369.

STOCK, G.N., GREIS, N.P. \& FISCHER, W.A. 2002. Firm size and dynamic technological innovation. Technovation, 22(9):537-549.

TETHER, B.S., 2002. Who co-operates for innovation, and why: an empirical analysis. Research Policy, 31(6):947-967.

THORNHILL, S. 2006. Knowledge, innovation and firm performance in high- and low-technology regimes. Journal of Business Venturing, 21:687-703.

TSAI, W. 2001. Knowledge transfer in intraorganizational networks: effects of network position and absorptive capacity on business unit innovation and performance. Academy of Management, 44(5):996-1004. WESTHEAD, P. \& COWLING, M. 1995. Employment change in independent owner-managed hightechnology firms in Great Britain. Small Business Economics, 7(2):111-140.

WESTHEAD, P. 1997. R\&D 'inputs' and 'outputs' of technology-based firms located on and off science parks. R\&D Management, 27(1):45-62.

YAMAMURA, E., SONOBE, T. \& OTSUKA, K. 2005. Time path in innovation, imitation and growth: the case of the motorcycle industry in postwar Japan. Journal of Evolutionary Economics, 15(2):169-186.

YANG, C., MOTOHASHI, K. \& CHEN, J. 2009. Are new technology-based firms located on science parks really more innovative? Evidence from Taiwan. Research Policy, 38(1):77-85.

ZAHRA, S.A. \& GEORGE, G. 2002. Absorptive capacity: a review, reconceptualization, and extension. Academy of Management Review, 27(2):185-203. 